Article

\title{
The Impact of Corporate Social Responsibility on Long-Term Relationships in the Business-to-Business Market
}

\author{
Hangeun Lee ${ }^{1}$ and Seong Ho Lee ${ }^{2, *(D)}$ \\ 1 College of Business, Chosun University, 309 Pilmundae-ro, Dong-gu, Gwangju 61452, Korea; \\ hglee.1007@chosun.ac.kr \\ 2 Department of Business Administration \& Accounting, Hanbat National University, Daejeon 34158, Korea \\ * Correspondence: 1sh33@hanbat.ac.kr; Tel.: +82-42-821-1376
}

Received: 3 September 2019; Accepted: 27 September 2019; Published: 28 September 2019

check for updates

\begin{abstract}
The purpose of this study is to investigate the effect of partner firms' corporate social responsibility (CSR) activities on long-term relationships in business-to-business (B2B) industries. We developed a research model to capture the correlations between a partner firm's CSR reputation (i.e., business practice, CSR reputation, and philanthropic CSR reputation), trust, information sharing, risk-reward sharing, and long-term relationships. Drawing on the stakeholder and social exchange theories, we hypothesized that a partner firm's CSR reputation would affect long-term relationships through trust, information sharing, and risk-reward sharing. Through empirical analysis, we found that business practice CSR is positively related to long-term relationships through trust and B2B partnership. We also present some theoretical and managerial implications of this study.
\end{abstract}

Keywords: business-to-business market; corporate social responsibility; B2B trust; risk and reward sharing; information sharing; long-term relationship

\section{Introduction}

Corporate social responsibility (CSR) has consistently been discussed as a strategic element for the sustainable management of firms. In particular, as stakeholder expectations for CSR have increased recently, the area of business-to-business (B2B) partnerships has been recognized as a significant strategic factor for long-term B2B relationships [1]. This is because a partner firm's reputation due to its CSR activities is a driving force for the formation of long-term relationships, and increases business value. In other words, the positive reputation of a partner firm may increase a company's value, but a negative reputation may undermine brand equity and customer loyalty [1-4].

Thus, in practice, a partner firm's reputation from CSR is an important issue in B2B relationships. For example, Nike has ended their 30-year-old relationship with Daewoo International, because Daewoo International engaged in child exploitation at a cotton factory in Uzbekistan, which led to a boycott of Nike's products and seriously affected Nike's brand value [5]. This example suggests that a company's social responsibility activities are a critical factor in building long-term relationships in B2B industries.

Despite the importance of CSR activities in B2B practice, research on this topic is limited [1]. This is because most previous studies take a business-to-customer (B2C) perspective, focusing on how various CSR activities affect customer satisfaction, purchase intention, and product evaluation [2-4]. In addition, existing research on B2B industries mostly focuses on CSR activities' implementation issues within supply chain management [6].

Therefore, we develop and empirically investigate the effect of a partner firm's CSR activities on long-term relationships in B2B industries. Specifically, this research involves the following. 
First, based on the stakeholder theory, this study divides CSR activities into two constituent concepts-business practice CSR and philanthropic CSR activities-and examines how they affect trust, a key factor of long-term B2B relationships.

Second, this study investigates how trust, with its reciprocal behaviors, plays a role in B2B relationships. Previous literature proposes that firms' reciprocal behaviors, such as information sharing and risk-reward sharing are core elements of B2B relationships [7]. Therefore, we empirically test how trust affects B2B relationships in terms of information sharing and risk-reward sharing.

Finally, we investigate the impact of information sharing and risk-reward sharing on long-term relationships. Through empirical research, we contribute to literature on B2B marketing and firms' sustainable management by identifying the effect of CSR activities on long-term B2B relationships. Figure 1 shows our research model.

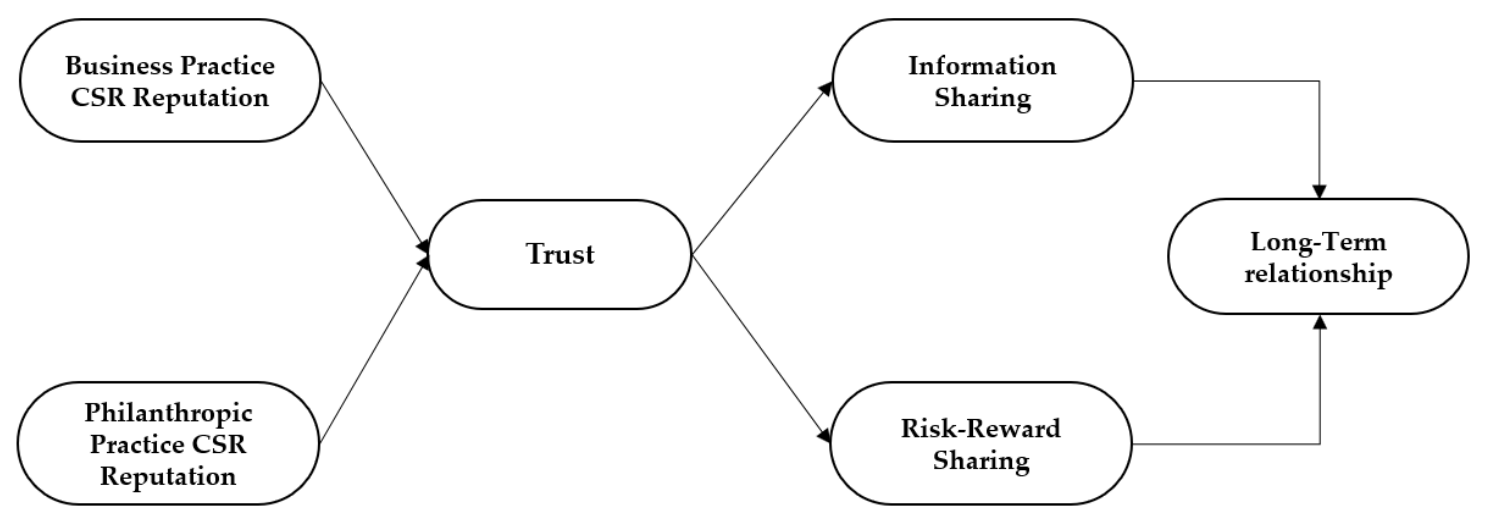

Figure 1. Research model. CSR: corporate social responsibility.

\section{Theory and Hypotheses}

\subsection{Busniess-to-Business Corporate Social Responsibility Activities}

Although existing research suggests that the concept of CSR activities is extensive [8,9], researchers mostly agree, with regard to CSR, that "the social responsibility of business encompasses the economic, legal, ethical, and discretionary expectations that society has of organizations at a given point in time" [10], and firms expect CSR activities to contribute to the firm's diverse assets, "congruent with prevailing social norms, values and expectations of performance" [11]. Therefore, CSR is defined as a commitment to improve social welfare through the contribution of business practices and corporate resources for employees and other stakeholders [12-14]. In view of this CSR concept, we differentiate CSR activities into two aspects, based on the stakeholder theory [1].

According to the stakeholder theory, a group or individual that surrounds a firm may affect or be affected by that firm's activities to achieve its purpose [15]. This means that stakeholder-directed activities are related to corporate performance $[16,17]$. Thus, based on the stakeholder theory, a firm's CSR activities may increase the value of stakeholders [1]. As a key principle, this theory divides stakeholders into primary and secondary stakeholders [15]. The primary stakeholder is "an entity that is involved in market exchanges (e.g., consumers, employees, partner firms, etc.) that directly affect firm performance" [18]. Among the primary stakeholders, consumers and partner firms are very important entities, as research suggests that these stakeholders have a profound influence on firm performance [1,9]. In contrast, secondary stakeholders are "those who affect or influence, be affected or influenced by, the firm, but are not involved in transaction of firms" [18]. Secondary stakeholders include communities, civil society organizations, and non-profit organizations, among others [19]. Existing research suggests that CSR, because of its nature, refers to a firm's ethical and philanthropic obligations [20]; thus, such CSR is focused on secondary stakeholders. Ethical obligations involve 
following the social and ethical norms in the business environment, while philanthropic obligations refer to activities that increase human welfare and goodwill outside corporate operations [21,22].

Therefore, this study divides CSR activities into two concepts, based on the stakeholder theory. First, we refer to CSR activities that reflect the characteristics of primary stakeholders as "business practice CSR activities" [1]. These CSR activities are considered a major factor in corporate management activities for stakeholders in market exchanges. Thus, business practice CSR activities focus on legal responsibility and compliance related to social responsibility, ethical obligations, and fair trade. This concept is in line with the ethical obligations identified by Carroll [21]. Second, we define "philanthropic CSR activities" as those reflecting the characteristics of secondary stakeholders who do not participate in transactions with the company, such as communities and non-profit organizations [1]. These activities refer to an entity's voluntary and altruistic behaviors, rather than the company's financial performance, in carrying out CSR activities. Thus, philanthropic CSR activities relate to community development, social welfare, and community service.

In addition, we use CSR reputation to measure the CSR activities of partner firms. This is because focal firms cannot evaluate the actual CSR activities of partner firms [1,23]. Hence, we refer to the perception of partner firms' CSR activities as "CSR reputation" [23]. Based on these concepts, we define business practice CSR reputation as the perception of a partner firm's CSR activities concerning primary stakeholders, whereas philanthropic CSR reputation is the perception of a partner firm's CSR activities concerning secondary stakeholders. Using these concepts of CSR activities, we empirically test the effect of partner firms' CSR activities on trust and B2B relationships.

\subsection{Busniess-to-Business Corporate Social Responsibility and Trust}

Existing research proposes that trust plays a very important role in B2B transactions, because it reduces problems caused by asymmetries of information and power between two parties [24]. Morgan and Hunt [25] argue that a firm trusts a B2B transaction when the partner firm has credibility and integrity. Trust constitutes a benefit for the partner firm, through a decrease in exchange uncertainty and reduction in transaction costs $[26,27]$. Therefore, trust in B2B transactions reinforces long-term relationships and improves firm performance $[25,28,29]$. In line with prior research on B2B relationships [1,30], we define trust as a firm's expectation that the partner firm is competent and has expertise (i.e., credibility or reliability), as well as the belief that the partner firm's intention is altruistic behavior (i.e., integrity or benevolence). According to the social exchange theory, long-term relationships in B2B transactions lead to trust-based results through an instrumental route that promotes transaction exchanges by reducing uncertainty, and an expressive route that appears when one party becomes attached to the other party [26].

The core of trust within an exchange relationship is the assumption that it is easier to trust when the trustee's behavior is predictable, and the trustor has the ability to predict this behavior [31]. Applied to our context, suppliers can deliver trustworthiness to partner firms by conveying signals about unobservable organizational attributes to enhance predictability [1,32]. Thus, we suggest that a strong CSR reputation can serve as a signal for positive firm characteristics. In particular, existing literature proposes that positive CSR activities impact a firm's reputation-that is, its credibility and integrity [2,33], which are essential factors of trust. Accordingly, we propose that from the focal firm's perspective, CSR reputation should be an indicator of the partner firm's trustworthiness. According to the signaling theory, unobservable signals (in this case, CSR reputation) are important for determining the effect of information cues [32].

In this context, business practice CSR reputation of partner firms serves as a cue for focal firms' reliability, because this CSR reputation is related to the partner firms' credibility in terms of fulfilling their business promise. Thus, business practice CSR reputation has a positive impact on trust in B2B partnerships. On the other hand, philanthropic CSR activities refer to the altruistic behavior of firms [1]. Implementation of these activities increases the benevolence and integrity of firms as it 
benefits non-profit organizations or communities. Therefore, philanthropic CSR reputation signals the focal firms' trustworthiness. Accordingly, the following hypotheses are established in this study:

H1a: Business-practice CSR reputation has a positive effect on trust.

H1b: Philanthropic CSR reputation has a positive effect on trust.

\subsection{Trust and Information Sharing}

According to the relational exchange theory [34,35], information sharing is recognized as an assurance tool for relationships between partner firms. Interfirm information sharing means that each firm freely shares and exchanges sensitive strategic and tactical information [36]. In a business environment, a firm's information (e.g., product-related information, demand forecasts, and cost-related information) is a very sensitive element, because such information is directly related to firm performance [36]. However, there is an imbalance of information among firms, in terms of both information quantity and quality, because of a disparity among firms in their ability to collect and process information [37]. Information sharing in a B2B relationship can address this information imbalance [38]. Therefore, information sharing between partner firms plays a vital role in B2B relationships [34].

According to previous research, information sharing is possible when trust is built between partner firms [35]. First, firms in a partnership exchange complementary resources by following the reciprocity principle $[30,35]$. This means that a focal firm is willing to share information only if it believes the partner firm has the necessary capability to do what the partner firm expects. Second, trust means that the focal firm highly values the altruism of the partner company [39]. Hence, the firm believes that the partner firm will perform better by leveraging the information provided to the partner for mutual benefit. In addition, the focal firm would not suspect that the informal and strategic information provided by the partner firm might be false information [40]. Therefore, we suggest the following hypothesis:

H2: Trust has a positive effect on B2B information sharing.

\subsection{Trust and Risk-Reward Sharing}

Risk-reward sharing is one of the most important characteristics of B2B cooperation, because partner firms share the risk and reward to improve one another [36]. Cooperation between partner firms also involves inherent risk, such as the rise of opportunistic behavior [41]. In a similar vein, $\mathrm{Xu}$ and Beamon [42] suggest that balancing shared risk and reward is the most important factor in corporate cooperative behavior. That is, if a focal firm does not receive enough compensation for its level of contribution to partner firms, it will not take risks related to the partnership. Thus, risk-reward sharing is a fundamental element of the B2B relationship [41].

Existing research proposes that trust increases risk-reward sharing [36]. Trusted partnerships not only pursue mutual benefits, but sometimes partner firms also sacrifice themselves for long-term relationships. In other words, if a particular risk arises in an exchange relationship, a focal firm with high level of trust from the partner firm will try to maintain the transaction relationship appropriately, even if it involves sacrifice. Ganesan and Hess [39] argue that partner firms with high levels of trust are willing to perform risk-tolerant cooperative activities for mutual benefit. Therefore, this study establishes the following hypothesis:

H3: Trust has a positive impact on B2B risk-reward sharing.

\subsection{Information Sharing, Risk-Reward Sharing, and Long-Term Relationships}

Information sharing encourages the active cooperation of partner firms [43]. In particular, sharing information through a cooperative relationship creates valuable information that improves 
the performance of each company and creates long-term relationships between partner firms [44,45]. In addition, risk-reward sharing strengthens partnerships between firms by inducing them to take risks and make sacrifices in their B2B relationships [39]. Xu and Beamon [42] also argue that high collaboration mechanisms, based on risk-reward sharing between partner firms, have a positive impact on the performance of participating firms, such as their marketing performance and interfirm relationships. Therefore, we establish the following hypotheses:

H4a: B2B information sharing has a positive impact on long-term relationships.

H4b: B2B risk-reward sharing has a positive impact on long-term relationships.

\section{Methodology}

\subsection{Data Collection and Sampling}

The unit of analysis in this study is B2B partnership. We collected data on such relationships by surveying marketing managers and purchasing managers from B2B firms. In particular, we collaborated with market research institutes to obtain information on marketing and purchasing managers in various B2B industries in South Korea. We asked them to fill out a self-administered questionnaire on the constructs of this study, such as partner firm's CSR activities. We collected 201 complete responses, excluding missing data, out of the 300 questionnaires initially distributed. We present the characteristics of the samples in Table 1.

Table 1. The characteristics of the sample.

\begin{tabular}{cccc}
\hline Construct & Items & Frequency & \% \\
\hline \multirow{4}{*}{ Industry } & Automotive parts & 43 & 21.4 \\
& Electronics & 26 & 12.9 \\
& Food and stimulants & 60 & 29.9 \\
& Fashion & 34 & 16.9 \\
& Sports & 11 & 5.5 \\
& Other & 27 & 13.4 \\
\hline \multirow{3}{*}{ Position of respondents } & Purchasing manager & 91 & 45.3 \\
& Marketing manager & 64 & 31.8 \\
& General manager & 46 & 22.9 \\
\hline
\end{tabular}

\subsection{Measurement Scales}

To develop measurements for research purposes, we used the scales adopted in the previous study. We applied a reflective measurement approach and five-point Likert scales for all multi-item constructs (see Appendix A). Business-practice CSR reputation and philanthropic CSR reputation were measured by three items taken and adapted from the research of Homburg et al. [1]. Trust was measured by three items taken and adapted from the research of Doney and Cannon [30]. Similarly, information sharing and risk-reward sharing was measured by three items taken and adapted from the research of Min et al. [36]. Finally, we measured long-term relationships with four items adapted from the research of Ganesan [46].

\subsection{Control Variable: Firm Size}

Previous studies have shown that firm size is often used as a control variable. The reason for using firm size as a control variable is that large firms may have more resources to implement CSR programs $[14,47,48]$. Thus, we controlled firm size in this research. The existing research used total assets, sales, or the number of employees to measure firm size $[47,49]$. This study used company sales in 2018 to measure firm size. 


\section{Results}

\subsection{Reliability, Validity, and Common Method Bias}

This study uses the following measures: business practice CSR reputation, philanthropic CSR reputation, trust, information sharing, risk-reward sharing, and long-term relationships. Following Anderson and Gerbing [50], Bagozzi and Yi [51], and Fornell and Larcker [52], assessment of the measures employs a three-step approach: (1) confirmatory factor analysis (CFA) of the measures, (2) analysis of validity (convergent and discriminant validity), and (3) test for common method bias.

First, CFA was performed using AMOS 18, to test the fit of the measurement model. The results indicate that the measurement model showed an acceptable model fit $\left(\chi^{2}{ }_{(120)}=183.742\right.$; Comparative Fit Index $(\mathrm{CFI})=0.960$; Tucker Lewis index $(\mathrm{TLI})=0.949$; Incremental Fit Index $(\mathrm{IFI})=0.961$; Root Mean Square Error of Approximation (RMSEA) = 0.052). Additionally, results for Cronbach's alpha greater than 70 show that all constructs exhibit good internal consistency [53] (see Table 2).

Table 2. Results of the confirmatory factor analysis (CFA).

\begin{tabular}{|c|c|c|c|c|c|}
\hline Construct & Items & $\lambda$ & $\alpha$ & CR & AVE \\
\hline \multirow{3}{*}{ Business practice CSR reputation } & B_CSR_01 & $0.612 *$ & \multirow{3}{*}{0.768} & \multirow{3}{*}{0.766} & \multirow{3}{*}{0.542} \\
\hline & B_CSR_02 & $0.755^{*}$ & & & \\
\hline & B_CSR_03 & $0.826^{*}$ & & & \\
\hline \multirow{3}{*}{$\begin{array}{l}\text { Philanthropic } \\
\text { CSR reputation }\end{array}$} & P_CSR_01 & 0.787 * & \multirow{3}{*}{0.794} & \multirow{3}{*}{0.795} & \multirow{3}{*}{0.566} \\
\hline & P_CSR_02 & 0.758 * & & & \\
\hline & P_CSR_03 & $0.710 *$ & & & \\
\hline \multirow{3}{*}{ Trust } & Trust_1 & $0.847 *$ & \multirow{3}{*}{0.853} & \multirow{3}{*}{0.876} & \multirow{3}{*}{0.662} \\
\hline & Trust_2 & $0.776^{*}$ & & & \\
\hline & Trust_3 & $0.817^{*}$ & & & \\
\hline \multirow{3}{*}{ Information sharing } & IS_1 & 0.839 * & \multirow{3}{*}{0.827} & \multirow{3}{*}{0.844} & \multirow{3}{*}{0.620} \\
\hline & IS_2 & $0.772 *$ & & & \\
\hline & IS_3 & $0.749 *$ & & & \\
\hline \multirow{3}{*}{ Risk-reward sharing } & RS_1 & 0.564 * & \multirow{3}{*}{0.743} & \multirow{3}{*}{0.733} & \multirow{3}{*}{0.515} \\
\hline & RS_2 & $0.782 *$ & & & \\
\hline & RS_3 & $0.785 *$ & & & \\
\hline \multirow{3}{*}{ Long-term relationship } & LO_1 & $0.682 *$ & \multirow{3}{*}{0.817} & \multirow{3}{*}{0.840} & \multirow{3}{*}{0.617} \\
\hline & LO_2 & $0.856^{*}$ & & & \\
\hline & LO_3 & 0.809 * & & & \\
\hline
\end{tabular}

Note: $\lambda=$ factor loading; $\alpha=$ reliability coefficient; CR: composite reliability; AVE: average variance extracted; CSR: corporate social responsibility; ${ }^{*} p<0.01$.

To further assess the constructs' convergent and discriminant validity, we followed Fornell and Larcker's [52] framework by calculating the average variance for each construct, and a significant $t$-statistic was obtained for each path. As shown in Table 2, each item was loaded on its respective underlying concept, and all loadings were significant. Moreover, each construct had an average variance extracted (AVE) of over 50 and a composite reliability of over 70, providing evidence of convergent validity.

In addition, as shown in Table 3, the value of the square root of the AVE for each construct exceeded the correlations between that construct and others. Hence, it has been confirmed that each construct in the study has discriminant validity. 
Table 3. Correlation and squared root of the average variance extracted.

\begin{tabular}{ccccccc}
\hline & $\mathbf{1}$ & $\mathbf{2}$ & $\mathbf{3}$ & $\mathbf{4}$ & $\mathbf{5}$ & $\mathbf{6}$ \\
\hline 1. Business practice CSR reputation & $0.736^{+}$ & & & & & \\
2. Philanthropic CSR reputation & $0.704^{* *}$ & $0.752^{+}$ & & & & \\
3. Trust & $0.598^{* *}$ & $0.506^{* *}$ & $0.813^{+}$ & & & \\
4. Information sharing & $0.399^{* *}$ & $0.504^{* *}$ & $0.441^{* *}$ & $0.787^{+}$ & & \\
5. Risk-reward sharing & $0.261^{* *}$ & $0.412^{* *}$ & $0.432^{* *}$ & $0.518^{* *}$ & $0.717^{+}$ & \\
6. Long-term relationships & $0.539^{* *}$ & $0.671^{* *}$ & $0.452^{* *}$ & $0.437^{* *}$ & $0.471^{* *}$ & $0.785^{+}$ \\
\hline
\end{tabular}

Finally, we examined for common method errors using Harman's single-factor test [54]. Common method bias was checked with a one-factor analysis, using exploratory factor analysis (EFA) to identify if only one general factor arises from all of the indicator variables. The EFA results show that six different factors have Eigenvalues of 1 or higher, and the first factor explains only $13.09 \%$ of the variance. Thus, the problem of common method bias was not found in this study.

\subsection{Hypothesis Testing}

The study used the structural equation model (SEM) to test the hypotheses. This study applied an AMOS approach, with maximum likelihood estimation for covariance structure analysis [50]. First of all, to test the potential endogeneity problem, we use two-stage least-squared methods (2SLS) proposed by Bollen [55] in our SEM study. This method is meant to remove the influence of mark variables (such as variables related to the main endogenous variables) on exogenous variables [56]. As a result of applying customer orientation as mark variable, we found that the fit of the research model was unacceptable. However, we confirmed that the fit indices of the proposed research model are acceptable $\left(\chi^{2}(142)=281.093 ; p<0.05 ; \mathrm{CFI}=0.913 ; \mathrm{TLI}=0.895 ; \mathrm{IFI}=0.914 ; \mathrm{RMSEA}=0.070\right)$. We also controlled firm size for all hypothesis (see Table 4).

$\mathrm{H} 1 \mathrm{a}$ and $\mathrm{H} 1 \mathrm{~b}$ are about the effects of CSR reputation on trust. Examination of these hypotheses showed that business practice CSR reputation has a positive effect on trust $(\beta=0.453 ; t=3.506 ; p<0.01)$, while philanthropic CSR reputation has an insignificant effect on trust. Hence, H1a is supported, but H1b is not supported.

The study hypothesized that trust has a significant positive effect on interfirm information sharing $(\mathrm{H} 2)$ and risk-reward sharing $(\mathrm{H} 3)$. Hypotheses testing showed that trust has a significant positive effect on both interfirm information sharing $(\beta=0.504 ; t=6.210 ; p<0.01)$ and risk-reward sharing $(\beta=$ $0.490 ; t=4.952 ; p<0.01)$. Therefore, $\mathrm{H} 2$ and $\mathrm{H} 3$ are also supported.

Finally, we find the positive effect of information sharing on long-term orientation $(\beta=0.290$; $t=3.498 ; p<0.01$ ). We also identified the positive link between risk-reward sharing and long-term relationships $(\beta=0.367 ; t=3.805 ; p<0.01)$. Thus, $\mathrm{H} 4 \mathrm{a}$ and $\mathrm{H} 4 \mathrm{~b}$ are supported.

Table 4. Results of hypotheses testing.

\begin{tabular}{cccc}
\hline Hypothesis & Path & Standard $\beta$ & $t$-Value \\
\hline H1a & Business practice CSR reputation $\rightarrow$ Trust & $0.453^{* *}$ & 3.506 \\
$\mathrm{H} 1 \mathrm{~b}$ & Philanthropic CSR reputation $\rightarrow$ Trust & 0.229 & 1.887 \\
$\mathrm{H} 2$ & Trust $\rightarrow$ Information sharing & $0.507^{* *}$ & 6.254 \\
$\mathrm{H} 3$ & Trust $\rightarrow$ Risk-reward sharing & $0.489^{* *}$ & 4.942 \\
$\mathrm{H} 4 \mathrm{a}$ & Information Sharing $\rightarrow$ Long-term relationships & $0.295^{* *}$ & 3.514 \\
$\mathrm{H} 4 \mathrm{~b}$ & Risk-Reward sharing $\rightarrow$ Long-term relationships & $0.366^{* *}$ & 3.786 \\
& Firm Size $\rightarrow$ Trust & -0.026 & -0.405 \\
Control & Firm Size $\rightarrow$ Information Sharing & 0.066 & 0.948 \\
variable & Firm Size $\rightarrow$ Risk-reward sharing & -0.026 & -0.352 \\
& Firm Size $\rightarrow$ Long-term relationships & -0.015 & -0.214 \\
\hline
\end{tabular}

Note: ${ }^{* *} p<0.01$. CSR: corporate social responsibility. 


\section{Discussion}

Recently, CSR activity has been considered to be a very important issue for B2B exchange relationships. Therefore, this study empirically examined the effect of CSR activities on long-term B2B relationships. The results revealed that business practice CSR reputation has a positive effect on trust, and it can serve as a cue about the partner company's credibility with regard to transaction stability and transparency. However, philanthropic CSR reputation had no significant effect on trust. We argue that the reason for this result is that B2B transactions are focused on partner firms' capabilities, compared to philanthropic CSR reputation, due to the high purchasing risk. On the other hand, we find that trust has a positive effect on both information sharing and risk-reward sharing. Finally, we show that information sharing and risk-reward sharing have a positive impact on long-term relationships. These results indicate that B2B CSR activities have a positive effect on B2B relationships.

\subsection{Theoretical Contributions}

Our study starts with an existing study of CSR-related outcomes focused on the B2C context. However, because of the distinctive decision-making characteristics of organizational buyers, the consequences of CSR's impact in the B2C context are not easily transferred to the B2B context. Therefore, this study contributes to understanding how CSR activities affect the long-term relationship between partner companies in the B2B context. In this regard, the specific theoretical implications of this study are as follows.

First, although previous studies argue that CSR activities play an important role in B2B relationships, empirical research on this topic is insufficient. In particular, most previous research focuses on the effects of CSR activities from a B2C perspective. Therefore, we make an academic contribution by empirically identifying the role of CSR in B2B exchange relationships. Second, we provide a theoretical framework for the consequences of CSR activities for long-term B2B relationships, by integrating the stakeholder and social exchange theories. Finally, this study has contributed to B2B CSR literature by empirically determining that business practice CSR activities drive long-term relationships through trust and B2B partnerships (information sharing and risk-reward sharing), revealing the mechanisms of such long-term relationships.

\subsection{Practical Contributions}

Our study has several practical implications. First, firms seeking long-term relationships can strategically exploit the CSR activities of partner firms. For example, if a focal firm prefers a long-term relationship with a partner firm, it may be possible to select a partner firm with a good business practice CSR reputation. Although this cannot serve as an absolute criterion for selecting partner firms, the type of CSR activity they conduct could be used to reduce the risk associated with opportunistic behavior that may arise in the exchange relationship.

Second, firms can strategically manage their CSR reputation to form long-term relationships with partner firms. For example, by increasing their reputation through business practice CSR activities related to compliance, ethical standards, etc., firms would be able to not only sustain their current relationships with customers, but also have a positive impact on potential customers.

Third, B2B managers should continuously analyze their roles in customer-based CSR activities, because focus on the principle of socially responsible purchasing is constantly increasing. In particular, CSR activities are critical in a market where consumers are strongly CSR-oriented, because such consumers regard both the company that manufactures a product and partner firms that do business with it as the same overall company. Therefore, B2B managers should have a continuing interest in the CSR activities of partner firms to ensure a sustainable competitive advantage.

Finally, B2B managers can use CSR as a strategic tool for long-term tactics, not just corporate ethical aspects. By including the CSR program in the contract terms, a focal firm can have a positive impact on the long-term relationship between partner companies. In addition, a focal firm may gain a 
first mover advantage by emphasizing CSR in the current market. Therefore, CSR is a key element of strategic marketing for corporate success, and a vital factor in marketing strategy.

\subsection{Limitations and Future Study Directions}

Although this study has various implications in terms of the role of CSR in long-term B2B relationships, there are some limitations, and the need for future research must be addressed.

First, this study used a self-reported survey and measured all the constructs simultaneously, which is a limitation. Although a problem with common method bias has not been found in this study, we cannot consider that the problem has been solved completely. Therefore, we suggest that further research using a longitudinal study design should be conducted to address this issue.

Second, although this study proposed and demonstrated theoretical models of B2B CSR and long-term relationships, various contingency factors of the business were not considered. According to the contingency theory, the leverage strength of corporate resources differs depending on market changes [57]. This means that B2B CSR may have a discriminatory effect on long-term relationships with partner firms depending on the various business environments, such as in terms of market dynamics and technical uncertainty. Thus, further research could present implications by identifying the moderating effects of various business environments on B2B CSR and long-term relationships.

Third, the endogeneity problem was not found in this study, but it was not completely solved. This is because structural limitations using the questionnaire method and all unobservable variables cannot be identified. Nevertheless, future research should seek to solve the endogeneity problem by finding variables that could potentially affect possible business performance. For example, CEO characteristics can potentially impact CSR and corporate performance [58]. In addition, structural characteristics of a company, such as corporate governance, can affect performance. Thus, we propose that future studies will need to consider a variety of unobservable variables, in order to find a more robust causal relationship.

Finally, although this study approaches the effectiveness of CSR through stakeholder theory and social exchange theory, other approaches are also possible. For example, because corporate governance is an important variable for corporate performance [59], future research will identify the effectiveness of CSR from the structural perspective of the firm. On the other hand, future research needs to identify the various effectiveness of CSR. For example, future research should examine how CSR activities affect a company's risk management [60], or how CSR affects a CEO's decision making. Therefore, we suggest that future research should examine useful effects of CSR in various contexts.

Author Contributions: S.H.L. organized the models and finalized the paper, and H.G.L. conceptualized the model, analyzed the data, and prepared the draft.

Funding: This research received no external funding.

Acknowledgments: This research was supported by Hanbat National University and Chosun University.

Conflicts of Interest: The authors declare no conflict of interest.

\section{Appendix A}

Business Practice CSR Reputation:

1. Our partner firms provide working conditions that safeguard the health and safety of their employees

2. Our partner firms follow high ethical standards in their business operations.

3. Our partner firms respect customer rights beyond the legal requirements.

Philanthropic CSR Reputation:

1. Our partner firms give back to the communities in which they do business.

2. Our partner firms integrate charitable contributions into their business activities. 
3. Our partner firms are involved in corporate giving.

Trust:

1. We believe the information our partner firms provide us.

2. Our partner firms are trustworthy.

3. When making important decisions, our partner firms consider our welfare as well as their own. Information sharing:

1. Our partner firms practice electronic data interchange, either via a VAN (value added network) or the internet.

2. Our partner firms regularly (at least once a quarter) exchange supply and demand forecasts with each other.

3. Our partner firms frequently (at least once a month) exchange demand change information with each other, to facilitate operational plans and reduce reliance on second-guesses.

Risk and reward sharing:

1. Our partner firms share risks and rewards.

2. Our partner firms help each other to finance capital equipment.

3. Our partner firms share research, development costs, and results with each other.

Long-term orientation:

1. Maintaining a long-term relationship with our partner firms is important to us.

2. We share our long-term goals with our partner firms.

3. We would like to develop a long-term relationship with our partner firms.

\section{References}

1. Homburg, C.; Stierl, M.; Bornemann, T. Corporate social responsibility in business-to-business markets: How organizational customers account for supplier corporate social responsibility engagement. J. Mark. 2013, 77, 54-72. [CrossRef]

2. Bhattacharya, C.B.; Sen, S. Consumer-company identification: A framework for understanding consumers' relationships with companies. J. Mark. 2003, 67, 76-88. [CrossRef]

3. Brown, T.J.; Dacin, P.A. The company and the product: Corporate associations and consumer product responses. J. Mark. 1997, 61, 68-84. [CrossRef]

4. Lichtenstein, D.R.; Drumwright, M.E.; Braig, B.M. The effect of corporate social responsibility on customer donations to corporate-supported nonprofits. J. Mark. 2004, 68, 16-32. [CrossRef]

5. Kim, Y. Ugly truth behind banknotes. The Korea Times. Available online: http://www.koreatimes.co.kr/www/ news/culture/2013/12/316_147819.html(accessed on 12 December 2013).

6. Tate, W.L.; Ellram, L.M.; Kirchoff, J.F. Corporate social responsibility reports: A thematic analysis related to supply chain management. J. Supply Chain Manag. 2010, 46, 19-44. [CrossRef]

7. Mentzer, J.T.; Min, S.; Zacharia, Z.G. The nature of interfirm partnering in supply chain management. J. Retail. 2000, 76, 549-568. [CrossRef]

8. Barnett, M.L. Stakeholder influence capacity and the variability of financial returns to corporate social responsibility. Acad. Manag. Rev. 2007, 32, 794-816. [CrossRef]

9. Maignan, I.; Ferrell, O.C. Corporate social responsibility and marketing: An integrative framework. J. Acad. Mark. Sci. 2004, 32, 3-19. [CrossRef]

10. Carroll, A.B. A three-dimensional conceptual model of corporate performance. Acad. Manag. Rev. 1979, 4, 497-505. [CrossRef]

11. Sethi, S.P. Dimensions of corporate social responsibility performance: An analytical framework. Calif. Manag. Rev. 1975, 17, 58-64. [CrossRef]

12. Carroll, A.B. Corporate social responsibility: The centerpiece of competing and complementary frameworks. Organ. Dyn. 2015, 44, 87-96. [CrossRef] 
13. Du, S.; Bhattacharya, C.B.; Sen, S. Corporate social responsibility, multi-faceted job-products, and employee outcomes. J. Bus. Ethics 2015, 131, 319-335. [CrossRef]

14. Kiessling, T.; Isaksson, L.; Yasar, B. Market orientation and CSR: Performance implications. J. Bus. Ethics 2016, 137, 269-284. [CrossRef]

15. Freeman, R.E. Strategic Management: A Stakeholder Approach; Harper Collins: Boston, MA, USA, 2010.

16. Donaldson, T.; Preston, L.E. The stakeholder theory of the corporation: Concepts, evidence, and implications. Acad. Manag. Rev. 1995, 20, 65-91. [CrossRef]

17. Freeman, R.E. Divergent stakeholder theory. Acad. Manag. Rev. 1999, 24, 233-236. [CrossRef]

18. Clarkson, M.E. A stakeholder framework for analyzing and evaluating corporate social performance. Acad. Manag. Rev. 1995, 20, 92-117. [CrossRef]

19. Lankoski, L. Differential economic impacts of corporate responsibility issues. Bus. Soc. 2009, 48, $206-224$. [CrossRef]

20. Carroll, A.B.; Shabana, K.M. The business case for corporate social responsibility: A review of concepts, research and practice. Int. J. Manag. Rev. 2010, 12, 85-105. [CrossRef]

21. Carroll, A.B. The pyramid of corporate social responsibility: Toward the moral management of organizational stakeholders. Bus. Horiz. 1991, 34, 39-48. [CrossRef]

22. Peloza, J.; Shang, J. How can corporate social responsibility activities create value for stakeholders? A systematic review. J. Acad. Mark. Sci. 2011, 39, 117-135. [CrossRef]

23. Wagner, T.; Lutz, R.J.; Weitz, B.A. Corporate hypocrisy: Overcoming the threat of inconsistent corporate social responsibility perceptions. J. Mark. 2009, 73, 77-91. [CrossRef]

24. Cook, K.S.; Cheshire, C.; Gerbasi, A.M. Power, dependence and social exchange. In Contemporary Social Psychological Theories; Burke, P.J., Ed.; Stanford University Press: Stanford, CA, USA, 2006.

25. Morgan, R.M.; Hunt, S.D. The commitment-trust theory of relationship marketing. J. Mark. 1994, 58, $20-38$. [CrossRef]

26. Lawler, E.J.; Thye, S.R.; Yoon, J. Emotion and group cohesion in productive exchange. Am. J. Sociol. 2000, 106, 616-657. [CrossRef]

27. Kollock, P. The emergence of exchange structures: An experimental study of uncertainty, commitment, and trust. Am. J. Sociol. 1994, 100, 313-345. [CrossRef]

28. Anderson, J.C.; Narus, J.A. A model of distributor firm and manufacturer firm working partnerships. J. Mark. 1990, 54, 42-58. [CrossRef]

29. Moorman, C.; Deshpande, R.; Zaltman, G. Factors affecting trust in market research relationships. J. Mark. 1993, 57, 81-101. [CrossRef]

30. Doney, P.M.; Cannon, J.P. An examination of the nature of trust in buyer-seller relationships. J. Mark. 1997, 61, 35-51. [CrossRef]

31. Huemer, L. Balancing between stability and variety: Identity and trust trade-offs in networks. Ind. Mark. Manag. 2004, 33, 251-259. [CrossRef]

32. Connelly, B.L.; Certo, S.T.; Ireland, R.D.; Reutzel, C.R. Signaling theory: A review and assessment. J. Manag. 2011, 37, 39-67. [CrossRef]

33. McWilliams, A.; Siegel, D. Corporate social responsibility: A theory of the firm perspective. Acad. Manag. Rev. 2001, 26, 117-127. [CrossRef]

34. Macneil, I.R. The New Social Contract: An Inquiry into Modern Contractual Relations; Yale University Press: New Haven, CT, USA, 1980.

35. Cannon, J.P.; Perreault, W.D., Jr. Buyer-seller relationships in business markets. J. Mark. Res. 1999, 36, 439-460. [CrossRef]

36. Min, S.; Mentzer, J.T.; Ladd, R.T. A market orientation in supply chain management. J. Acad. Mark. Sci. 2007, 35, 507-522. [CrossRef]

37. Gundlach, G.T.; Cannon, J.P. "Trust but verify"? The performance implications of verification strategies in trusting relationships. J. Acad. Mark. Sci. 2010, 38, 399-417. [CrossRef]

38. Singh, J.; Sirdeshmukh, D. Agency and trust mechanisms in consumer satisfaction and loyalty judgments. J. Acad. Mark. Sci. 2000, 28, 150-167. [CrossRef]

39. Ganesan, S.; Hess, R. Dimensions and levels of trust: Implications for commitment to a relationship. Mark. Lett. 1997, 8, 439-448. [CrossRef] 
40. Levin, D.Z.; Cross, R. The strength of weak ties you can trust: The mediating role of trust in effective knowledge transfer. Manag. Sci. 2004, 50, 1477-1490. [CrossRef]

41. Matopoulos, A.; Vlachopoulou, M.; Manthou, V.; Manos, B. A conceptual framework for supply chain collaboration: Empirical evidence from the agri-food industry. Supply Chain Manag. 2007, 12, 177-186. [CrossRef]

42. Xu, L.; Beamon, B.M. Supply chain coordination and cooperation mechanisms: An attribute-based approach. J. Supply Chain Manag. 2006, 42, 4-12. [CrossRef]

43. Johnsen, T.E. Supplier involvement in new product development and innovation: Taking stock and looking to the future. J. Purch. Supply Manag. 2009, 15, 187-197. [CrossRef]

44. Sanzo, M.J.; Santos, M.L.; Vázquez, R.; Álvarez, L.I. The effect of market orientation on buyer-seller relationship satisfaction. Ind. Mark. Manag. 2003, 32, 327-345. [CrossRef]

45. Blesa, A.; Bigné, E. The effect of market orientation on dependence and satisfaction in dyadic relationships. Mark. Intell. Plan. 2005, 23, 249-265. [CrossRef]

46. Ganesan, S. Determinants of long-term orientation in buyer-seller relationships. J. Mark. 1994, 58, 1-19. [CrossRef]

47. Hull, C.E.; Rothenberg, S. Firm performance: The interactions of corporate social performance with innovation and industry differentiation. Strateg. Manag. J. 2008, 29, 781-789. [CrossRef]

48. Marcel, J.J. Why top management team characteristics matter when employing a chief operating officer: A strategic contingency perspective. Strateg. Manag. J. 2009, 30, 647-658. [CrossRef]

49. Dang, C.; Li, Z.F.; Yang, C. Measuring firm size in empirical corporate finance. J. Bank. Financ. 2018, 86, 159-176. [CrossRef]

50. Anderson, J.C.; Gerbing, D.W. Structural equation modeling in practice: A review and recommended two-step approach. Psychol. Bull. 1988, 103, 411. [CrossRef]

51. Bagozzi, R.P.; Yi, Y. On the evaluation of structural equation models. J. Acad. Mark. Sci. 1988, 16, 74-94. [CrossRef]

52. Fornell, C.; Larcker, D.F. Evaluating structural equation models with unobservable variables and measurement error. J. Mark. Res. 1981, 18, 39-50. [CrossRef]

53. Nunnally, J.C. Psychometric Methods; McGraw Hill: New York, NY, USA, 1978.

54. Podsakoff, P.M.; MacKenzie, S.B.; Podsakoff, N.P. Sources of method bias in social science research and recommendations on how to control it. Annu. Rev. Psychol. 2012, 63, 539-569. [CrossRef]

55. Bollen, K.A. An alternative two stage least squares (2SLS) estimator for latent variable equations. Psychometrika 1996, 61, 109-121. [CrossRef]

56. Jean, R.J.B.; Deng, Z.; Kim, D.; Yuan, X. Assessing endogeneity issues in international marketing research. Int. Mark. Rev. 2016, 33, 483-512. [CrossRef]

57. Collis, D.J. Research note: How valuable are organizational capabilities? Strateg. Manag. J. 1994, 15, $143-152$. [CrossRef]

58. Coles, J.L.; Li, Z.F. Managerial Attributes, Incentives, and Performance. 2018. Available online: https: //ssrn.com/abstract=1680484 (accessed on 13 September 2019). [CrossRef]

59. Giroud, X.; Mueller, H.M. Corporate governance, product market competition, and equity prices. J. Financ. 2011, 66, 563-600. [CrossRef]

60. Dunbar, C.G.; Li, Z.F.; Shi, Y. Corporate Social Responsibility and CEO Risk-Taking Incentives. 2017. Available online: https://ssrn.com/abstract=1680484 (accessed on 13 September 2019). [CrossRef]

(C) 2019 by the authors. Licensee MDPI, Basel, Switzerland. This article is an open access article distributed under the terms and conditions of the Creative Commons Attribution (CC BY) license (http://creativecommons.org/licenses/by/4.0/). 